\title{
The Politics of Evidence Use in Health Policy Making in Germany: The Case of Regulating Hospital Minimum Volumes
}

\author{
Stefanie Ettelt
}

\section{INTRODUCTION}

In Germany, the idea of evidence-based policy as a model of modern policy-making has not engendered as much enthusiasm as in other countries, particularly in the Anglo-Saxon world (Jun and Grabow 2008; Knieps 2009). German policy-makers and researchers are broadly in agreement that scientific evidence has become more relevant to policy-making over time to address increasingly complex policy problems and to provide legitimacy for potentially unpopular decisions (Renn 1995; Mayntz 2009).

This chapter presents an updated version of a paper first published as:

Ettelt, S. 2017. The politics of evidence use in health policy making in Germany - The case of regulating hospital minimum volumes. Journal of Health Politics, Policy and Law 42 (3): 513-538.

S. Ettelt $(\bowtie)$

London School of Hygiene and Tropical Medicine, London, UK e-mail: stefanie.ettelt@lshtm.ac.uk

(C) The Author(s) 2018

J. Parkhurst et al. (eds.), Evidence Use in Health Policy Making, International Series on Public Policy, https://doi.org/10.1007/978-3-319-93467-9_6 
There is also an ever growing demand for expertise met by an array of scientific advisory committees, research institutes, expert commissions and expert networks providing advice to government (Kloten 2006; Siefken 2007; Jun and Grabow 2008; Blum and Schubert 2013). This is particularly visible in health care policy, in which scientific evidence use has become institutionally embedded, for example, through the creation of the Institute for Quality and Efficiency in Health Care (Institut für Qualität und Wirtschaftlichkeit im Gesundheitswesen, IQWiG) (IQWiG 2015 ) as a provider of independent health technology assessments in the corporatist sector.

However, much scepticism about the role of scientific evidence exists outside the narrow confines of health technology assessment, with some commentators seeing references to evidence representing little more than 'scientifically cloaked lobbyism' (Knieps 2009). The complexity of the policy process in Germany - with its multitude of actors that exist within a federal, corporatist system, and the dominance of legislation over other forms of policy-making - would not lend itself to support notions of evidence-based policy.

Policy scholars have frequently noted the role of corporatism in health policy in Germany, which has given organised interests a central role in decision-making (Lehmbruch 1988; Lijphart and Crepaz 1991). The state has delegated a wide range of governance tasks to the respective associations of office-based doctors (i.e. family doctors as well as specialists), hospitals and sickness funds, which include, for example, decisions about public reimbursement of pharmaceuticals and medical services, and the definition of rules relating to quality assurance and reimbursement (Bandelow 2004). The same organised interests also have substantial influence on law making both at federal and state levels. For a long time, political parties had clear allegiances to specific interests, for example, the Social Democrats (SPD) tending to support the role of sickness funds while the Free Democrats (FDP) sought opportunities to extend the scope of private insurance, although these allegiances are not as clear as they used to be.

Provider organisations, especially those representing office-based doctors, used to be particularly influential and able to influence, and stymie, policy proposals as veto players within decision-making processes (Tsebelis 2011). Yet over the years the power dynamics between actors have 
changed, bringing about new patterns of organisational behaviour (Bandelow 2009). Consecutive reforms have strengthened sickness funds vis-à-vis provider organisations (e.g. by changing voting rules in committees) thus shifting the balance between payers and providers (Bandelow 2009). The federal government has also become more assertive in setting the national framework for corporatist decision-making. This was accompanied by the creation of new organisations through the merger of several associations of sickness funds into one, the Gemeinsame Spitzenverband, and by bringing together several committees to form the Federal Joint Committee (Gemeinsamer Bundesausschuss, GBA). The latter was aimed at professionalising and formalising the process of health policy-making and now forms the top decision-making body within the corporatist sector (Gerlinger 2010).

Traditional alliances have also weakened and lines of opposition have become blurred. Physicians associations now face the difficulty of representing doctors in primary and secondary care who are often pitched against each other in questions of resource allocation. Likewise, the German Hospital Association (Deutsche Krankenhausgesellschaft) represents all hospitals providing publicly funded services, irrespective of their size, ownership status and type of services provided. Policy changes such as the introduction of activity-based payments has also increased the competition between hospitals for patients and funding. Thus changes in policy - be they targeted at cost control or at securing quality of care increasingly affect provider organisations in different ways, making it more difficult for top associations to present a unified front. Commentators noted that while corporatist actors still wield substantial influence, the nature of corporatism has changed over time and become more pluralist, yet also more adversarial and less consensual in style (Bandelow 2004). These dynamics also play out in the 'legalistic culture' of German policymaking, in which law-making and legal adjudication are crucial constituents of the policy process (Strueck 2013). In this chapter, it is argued that the changing style of decision-making is also demonstrated in the increased role of evidence use for both substantiating and legitimising decisions.

This chapter will explore how health policy actors in Germany have used scientific evidence to promote their aims and objectives, using the case of minimum volumes as a pertinent example. Based on the idea that quality 
improves with greater experience in a given procedure ('practice makes perfect'), minimum volumes have been introduced for a number of highly specialised hospital services as a measure of improving quality of care. The policy has also been introduced at the time of the formation of the GBA as the top decision making body of the self-administration in health care. Given that the latest lawsuit only concluded in December 2015 the discussion about minimum policy allows for an analysis of the role of the GBA in professionalising health policy-making, which also changed the role of scientific evidence.

The chapter will examine the role of evidence at three different stages of the policy process:

- The making of the legislative framework taking place in the two chambers of parliament, the Federal Assembly (Bundestag) and Federal Council (Bundesrat);

- The definition of minimum volumes by the 'corporatist' selfadministration, represented by the GBA; and

- Legal adjudication in the social courts, charged with reviewing the legitimacy of minimum volumes set by the GBA.

It is not without irony that the idea of regulating minimum volumes as a measure of quality improvement was initially inspired by research: Studies in the United States suggested that hospitals that performed a larger number of highly complex surgeries produced better outcomes for patients than hospitals that provided these services less often (e.g. Birkmeyer et al. 1999). The idea of turning volume-outcome relationships into a policy proposal has been credited to health economist and university professor Karl Lauterbach who, at the time, was an influential policy advisory to the Federal Minister of Health Ulla Schmidt. Minimum volumes were passed into law in 2002 and have been specified and operationalised in the years that followed, attracting much controversy as well as legal challenge from hospitals.

The following section provides an introduction into the literature on strategic evidence use, followed by a description of the study methods and a summary of the scientific evidence base for minimum volumes. The middle section of the chapter is devoted to the analysis of the role of scientific evidence at different stages of the policy process. The chapter finishes with a discussion and conclusion. 
Table of key organisations and committees

\begin{tabular}{|c|c|c|}
\hline German & English & Function \\
\hline Ausschuss Krankenhaus & $\begin{array}{l}\text { Hospital } \\
\text { Committee }\end{array}$ & $\begin{array}{l}\text { Committee representing hospitals and } \\
\text { sickness funds, mandated with decision- } \\
\text { making for the hospital sector before } \\
2004\end{array}$ \\
\hline Bundesrat & Federal Council & $\begin{array}{l}\text { Chamber of parliament representing the } \\
\text { governments of the states (Länder) }\end{array}$ \\
\hline Bundestag & $\begin{array}{l}\text { Federal } \\
\text { Assembly }\end{array}$ & $\begin{array}{l}\text { Chamber of parliament representing } \\
\text { elected political parties }\end{array}$ \\
\hline Deutsche & German & Federal-level association of hospitals \\
\hline Krankenhausgesellschaft & $\begin{array}{l}\text { Hospital } \\
\text { Association }\end{array}$ & \\
\hline Gemeinsamer & Federal Joint & Top decision-making body of the \\
\hline Bundesausschuss (GBA) & Committee & $\begin{array}{l}\text { corporatist self-administration in health } \\
\text { care, since } 2004\end{array}$ \\
\hline Gesundheitsausschuss & $\begin{array}{l}\text { Health } \\
\text { Committee }\end{array}$ & $\begin{array}{l}\text { Parliamentary committee, preparing } \\
\text { health related legislation for the Bundestag }\end{array}$ \\
\hline Vermittlungsausschuss & $\begin{array}{l}\text { Mediation } \\
\text { Committee }\end{array}$ & $\begin{array}{l}\text { Parliamentary committing, mediating } \\
\text { between Bundestag and Bundesrat }\end{array}$ \\
\hline
\end{tabular}

\section{Strategic Uses of Evidence in Health Policy-Making}

Carol Weiss observed in her 1979 paper that scientific evidence can be used for at least seven purposes (Weiss 1979). 'Instrumental' use is what proponents of evidence-based policy usually have in mind when they demand for research findings to be taken account of in policy decisions. However, Weiss argued that research typically influences policy in more indirect ways, with knowledge from research filtering through to policymakers over time and in often far more convoluted ways than ideas of straight forward application would suggest. 'Political' use implies that policy-makers utilise scientific evidence in a more active manner, yet for specific, politically driven purposes. Such use, also often called 'symbolic' or 'tactical', is therefore always selective, with policy-makers choosing those pieces of evidence that best promote their case. For the purists of evidence-based policy, strategic use comes close to 'policy-based evidence', defeating the purpose of 'objective' science of making policy better informed and more rational (Marmot 2004). 
However, for scholars of the policy process, selective use is by no means a surprise. Majone (1989) was one of the first to argue that evidence is typically used as a means of persuasion as part of a political argument. Greenhalgh and Russell (2007) found that evidence is often selected to fit an "argumentation game" played by policy actors by employing rhetoric and mobilising considerations of plausibility and reasonableness to achieve their aims. From that perspective, evidence use is better described as constitutive of the "social drama" of policy-making rather than seen as an end in itself. Yet there is always the question of who uses evidence strategically and for which purpose. Hind, for example, has warned that both the state and corporations use science to legitimise their actions, which in his view constitutes a serious threat to reasoning and rationality, the core values of modern societies (Hind 2007).

The role of scientific evidence in legitimising decisions has also been extended to organisations. Boswell (2008), for example, has argued that scientific knowledge plays a key role in legitimising the role of the European Commission in immigration policy, a field that is frequently inflicted with controversy. A similar observation was made by Bijker et al. (2009) in their study of the Gezondheidsraad (Health Council) in the Netherlands. They observed that the Council successfully utilised the authority of science to legitimise its advice to policy, which occurs - paradoxically, as they argue despite the fact that contemporary society has become more critical of research and more aware of the limits of science (for example in relation to genetically modified food) (Weingart 1999). McNulty (2012) noted that aid organisations increasingly commission programme evaluation for the purpose of demonstrating compliance with expectations of accountability and transparency.

To be clear, the focus on strategic evidence use does not imply that scientific research is useless in informing policy-makers and in substantiating policy thinking in view of improving outcomes. However, it does raise the question of the motivation of policy-makers to use evidence and highlights the existence of considerations that have more to do with the nature of the policy process, the need to demonstrate accountability and the contested nature of decisions that affect the interests of policy actors than with conceptions of purely instrumental evidence use (Suchman 1995; Hansson 2006).

The case study of minimum volumes policy provides a pertinent example of evidence use in the face of conflicting interests played out in a corporatist system of health policy-making. The case also parallels controversies surrounding other decisions taken by the GBA, especially those to exclude or limit publicly funded services using health technology assessments 
(HTA) (Perleth et al. 2009; Kieslich 2012). Such decisions can be highly controversial and pharmaceutical companies often take the GBA to court to challenge unfavourable outcomes. The threat of legal challenge requires the GBA to demonstrate the legitimacy of such decisions and it does so by reference to evidence reviews, commissioned from IQWIG, among other things. The role of HTA in legitimating potentially unpopular decisions about resource allocation (i.e. prioritisation, rationing) has also been critically discussed in relation to NICE, the National Institute of Health and Clinical Excellence in England (Syrett 2003; Littlejohns 2012), which is internationally recognised as a leader in this field. Yet while the GBA has a similar mandate and procedural arrangements are in place that are comparable to NICE, the legal framework and corporatist structures in which the GBA is embedded differ from the institutional context of NICE. NICE decisions are ultimately politically sanctioned by Government (not corporatist actors) and are less likely to attract legal redress due to differences in legal practice, while the GBA as a corporatist decision-maker is exposed to both influences of corporatist interests and opportunities for legal challenge (Syrett 2004; Gress et al. 2005; Francke and Hart 2008; Landwehr and Böhm 2011; Klingler et al. 2013).

\section{Methods}

This case study is informed by documentary analysis and interviews. Documents include published protocols of parliamentary committees; published records of court decisions; selected articles from several broadsheet newspapers reporting on minimum volumes such as Der Spiegel, Frankfurter Allgemeine Zeitung and Die Zeit and from professional journals such as Deutsches Ärzteblatt; scientific reports published by IQWIG and by researchers commissioned to undertake evidence reviews; materials from websites such as policy documents relating to minimum volumes published by the GBA and by corporatist organisations, as well as press releases published by these organisations.

The documentary analysis has been supplemented by a number of interviews with key informants $(\mathrm{n}=9)$, representing various types of policy-makers (government bureaucracy; corporatist organisations) and researchers. Interviewees were selected because of their knowledge of, and/or known involvement in, the process of developing minimum volumes policy. The roles of individual interviewees will not be identified in the following analysis to ensure the level of anonymity and confidentiality agreed at interview. 


\section{Minimum Volumes in Hospital: Policy Idea and SCIENTIFIC Evidence}

Since the 1970s, health services research in the United States and elsewhere suggested that for certain services, typically complex surgery, hospitals that provided the service to a larger number of patients achieved better outcomes for patients (i.e. lower mortality and morbidity) than hospitals that provided the same service to a smaller number of patients (Luft et al. 1979). Interviewees suggested that studies published by Birkmeyer and colleagues in the 1990s and early 2000s were particularly influential in turning a statistically observed association of volume and outcomes into a policy idea (Birkmeyer et al. 1999, 2002, 2003; Finlayson et al. 2003). The idea also appealed to policy-makers as it resonated with the common sense notion that 'practice makes perfect'. Minimum volumes had already been ubiquitously used in medical training and accreditation, although they had not been used before to exclude hospitals from providing a service.

Regulating minimum volumes also fitted with the wider reform agenda for hospitals at the time. There were two concerns specifically: the perceived inefficiency and costliness of hospital care compared to other countries and emerging concerns about variation in the quality and outcomes of care. The first concern was to be addressed by the introduction of activity-based payments as the main method of funding hospitals (Busse and Blümel 2014). For their proponents, namely sickness funds, minimum volumes promised to speak to the second concern and to counter perceived risks to quality associated with the first.

However, despite being a policy idea inspired by scientific research, the scientific evidence base for operationalising the policy proved challenging. Evidence reviews suggested that there was a statistically significant relationship between higher volumes and improved outcomes for a number of complex surgical interventions such as pancreatic resection or oesophagectomy (Geraedts 2002; Rathmann and Windeler 2002; IQWiG 2005, 2008). These studies were typically observational (i.e. non-experimental) and were not considered as providing ultimate proof of causality. There were also limitations with regard to the data used in these studies, which typically relied on routinely collected information and were limited to certain populations or countries or groups of hospitals (e.g. in the US), raising questions about the transferability of their findings.

A further challenge was the difficulty of using studies indicating statistical correlations to support or set precise minimum volumes for specific 
procedures. Studies typically used definitions of 'high' and 'low' volumes of service provisions, but these were set by researchers and driven by data availability. In addition, most studies originated in the US, with studies using German data only emerging over time. But analyses of German data were also difficult to interpret and almost impossible to use to inform minimum volumes. For example, in 2006, IQWIG, the research institute associated with the GBA, published an analysis of data on volumes and outcomes of total knee replacement surgery, using two indicators of outcome quality (postsurgical mobility and infection) that produced conflicting findings (IQWiG 2006).

In sum, while there was scientific evidence to support the selection of services which could benefit from minimum volumes, there was limited evidence to guide the selection of the specific volumes to be set in these cases. This substantially reduced the potential for explicit "evidence based" decision-making when it came to setting volumes. Minimum volumes so far have not lent themselves to any straight forward translation of "evidence into policy". More importantly, however, they have been controversial from the outset, pitching against each other sickness funds as their proponents and hospitals as their vocal opposition. This conflict between payers and providers played out through all stages of the policy process with controversy surrounding the interpretation of the evidence often being at the centre of the argument. In addition, minimum volumes - as a regulatory policy - created winners and losers among hospitals, with smaller hospitals with fewer patients likely to lose out to large teaching hospitals. The opposition, represented in the German Hospital Association, was therefore not entirely unified, making it more difficult for hospitals to mount resistance.

\section{Devising the Legislative Framework}

In 2001, the Federal Government - then composed of Social Democrats and the Green Party - brought a proposal for major reform of hospital funding before parliament. The proposal involved replacing the previous method of paying hospitals via budgets and per diems (payments per day of hospital stay) through a funding approach predominantly based on activity-based payments using diagnosis-related groups. The aim of this reform was to reduce perceived inefficiencies in hospital funding, reduce the length of stay of hospital inpatients, which were one of the longest in Europe, and to increase competition between hospitals. Minimum volumes 
were introduced on the back of this reform, as a counter measure to known risks to quality associated with activity-based funding as its proponents argued (Interview). They had the added attraction - especially for sickness funds and Social Democrats - of excluding hospitals with lower volumes from providing certain services, thus providing a lever for facilitating structural change in the (difficult to reform) hospital market.

Although the idea of regulating volumes of complex hospital services was inspired by research, scientific evidence, unsurprisingly, did not feature widely in the parliamentary discussion in which the legal framework for minimum volumes was developed. Instead, the procedural rules of parliamentary decision-making show a much clearer imprint on the resulting legislation, published as part of the 2002 Act on Case-Based Payment (Fallpauschalengesetz). In relation to minimum volumes, the 2002 Act stipulated that the relevant decision-making body of the self-administration (at that time the Hospital Committee and, from 2004, the GBA) should identify hospital services for which "the quality of outcomes particularly depended on the volume of services provided" and set minimum volumes for such services (Bundestag 2002b). The Act has since been integrated into Social Code Book V, now forming part of paragraph 137.

As the bill concerned hospital funding it directly touched on the legal responsibilities of the states and therefore required approval of both chambers of parliament. In the Bundestag, the bill was discussed in the Health Committee, which introduced a number of amendments including that minimum volumes should only be applied to 'planable' services (planbar), thus excluding urgent or emergency services. The Health Committee (composed of members of the Bundestag reflecting the proportionate representation of its constituent political parties) also requested transitional arrangements for hospitals that wanted to invest in expanding or creating new services, for example, by employing a new specialist (Bundestag 2001a). While seemingly reducing the scope of minimum volumes, the Health Committee also sharpened the bill by making minimum volumes binding on hospitals (instead of using them as guidelines as an earlier version suggested) and by preventing sickness funds from reimbursing services if hospitals continued to provide them in insufficient numbers. Taken together, the changes introduced by the Health Committee both suited the agenda of sickness funds and, to some extent, may have mollified hospitals by limiting minimum volumes to elective services only. 
The states, represented in the Bundesrat, also made amendments to the bill as the documents of the Mediating Committee suggest. Specifically, the Committee (composed of members of the Bundestag and the Bundesrat) made provisions that allowed states to exempt individual hospitals from minimum volumes if they found access to services at risk within a given geographic area (Bundestag 2002a).

There is no indication in the documents examined that parliamentary committees concerned themselves with an interpretation of the scientific evidence available in support of minimum volumes. However, the resulting legislation, purposefully or unwittingly, included a clause where the specific wording lends itself to being interpreted as stipulating that specific minimum volumes had to be supported by scientific evidence. Specifically, the Act stated that "the quality of outcomes particularly depended on the volume of services provided" [emphasis added]. This clause had significant influence on how the law was subsequently interpreted and applied both by corporatist policy actors (i.e. the associations in favour and against, as well as the GBA as decision-making body) and by social courts involved in legal adjudication.

\section{Setting Minimum Volumes: The Role of the Federal Joint Committee}

With the passage of the Act, federal legislators mandated the selfadministration to identify hospital services suitable for minimum volumes and to set volume thresholds. This task fell initially to the Hospital Committee (Ausschuss Krankenhaus), formed by the top associations of sickness funds, the German Hospital Association and the Medical Association (Ärztekammer), and, from 2004, to the newly formed GBA.

The legal mandate required associations of sickness funds and hospitals (with participation from a number of other organisations such as private health insurers) to jointly identify the 'catalogue of planable services' and to set minimum volumes for these services (MMV 2002). As constituents of the committee, both (groups of) associations brought their own positions and interests of their members to the negotiating table. Sickness funds, as noted above, were keen to establish minimum volumes as a policy instrument for quality assurance and structural change. The hospital association, in contrast, wanted to prevent their introduction and, as this had failed, to limit the number of services minimum volumes would apply to and keep volume thresholds low. 
While unable to openly reject quality assurance as an objective, the main strategy of the hospital association was to highlight the risks to patients potentially arising from minimum volumes. These risks came in two flavours: The first argument was that minimum volumes would endanger access to care for patients by reducing the geographic coverage of services:

In addition, the proposed bill suggests minimum volumes for hospitals. Yet the application of minimum volumes can exclude hospitals [from service provision] in an unjustified way, which would endanger access to services for patients. [DKG, Press release, 1 Feb 02]

A second line of argument was that minimum volumes were insufficiently supported by scientific evidence and were 'unfair' to low-volume hospitals that would produce good outcomes (Interview). Legislators had pre-empted the first line of argument by allowing state authorities to grant exemptions on a case-by-case basis on the grounds of geographic equity. However, the second argument - insufficient evidence - was more successful in challenging the appropriateness of minimum volumes and obstructing their implementation. This position has been maintained to this day in a slightly modified version, with the hospital association arguing that service volumes as surrogate parameter being less meaningful and therefore more likely to be unfair than indicators that measure quality directly (DKG 2014). While this is scientifically correct, it also raises the bar for regulation as it is not at all clear how other quality indicators would be operationalised to impact on hospitals' practice of service provision.

A first list of complex surgical procedures was agreed by the Hospital Committee in 2003, comprising liver transplants, kidney transplants, complex surgery of the oesophageal system and the pancreatic system, and stem cell transplantation. For these services, thresholds were set between 5 and 20 per hospital per year (liver transplantation 10; kidney translation 20; oesophageal surgery 5 , pancreatic surgery 5 , stem cell transplantation 10-14) (MMV 2002).

Interviewees commented that these procedures had been considered as relatively uncontroversial, as their share in service delivery and potential financial impact on hospitals was small and volume thresholds low (Interview). They were also reflective of the services analysed in existing studies (Geraedts 2002; Rathmann and Windeler 2002). The limited selection of services and the low thresholds thus suggest compromise 
between hospital and sickness fund associations on the lowest common denominator. In contrast, minimum volumes proposed by sickness funds (e.g. the Verband der Angestellten-Krankenkassen) had been much more ambitious, for example, for oesophageal and pancreatic surgery (both 10), coronary surgery (100), carotid surgery (20), percutaneous transluminal coronary angioplasty (150), breast cancer surgery (150) (Geraedts 2002).

In 2004, following the formation of the GBA, two further procedures were added to the list: total knee replacement and coronary surgery (BMGS 2004). However, no volumes were set at the time and coronary surgery - arguably a high volume service - would not be pursued any further. More controversially, in 2005, a threshold of 50 cases per hospital and year was set for total knee replacements (BMGS 2005). Neonatal services for babies with very low birth weight were added by the GBA in 2009 (GBA 2009). These two decisions involving services with high volumes (knee replacement) and high costs (neonatal care) proved highly contested and were both subsequently challenged in court by hospitals.

At the time, two 'evidence reports' - one commissioned by sickness funds and authored by Rathmann and Windeler (2002) and the other commissioned by the Federal Chamber of Physicians and authored by Geraedts (2002) - appeared to have influenced the selection of services for minimum volumes. Both reports were able to identify procedures such as complex surgery of oesophageal tumours for which evidence of a robust volume-outcome relationship existed. However, as these studies were observational and relied on routine data, their authors took care to mention that the evidence did not lend itself to suggesting volume thresholds. They also pointed out that studies did not identify the mechanisms, or factors, that would explain why higher volumes produced better outcomes. In other words, while these reviews established the problem and provided a rationale for action, they were unable to suggest specific solutions.

However, despite the known limitations of the evidence base, the 2003 agreement stipulated that future minimum volumes should be based on scientific evidence. Specifically, it stated that decisions should be taken based on 'epidemiological and empirical knowledge' and applied in 'a transparent and rule-based process' (MMV 2002: 1). Not only should future minimum volumes require evidence of a causal relationship between volume and outcomes, they also required proof that improved outcomes were predominantly caused by higher volumes ('im überwiegenden Teil). Thus the 2003 agreement suggested that minimum volumes should only be set if volume was proven to be the decisive factor for variation in 
outcomes. This wording echoed similar terminology in the law ('in besonderem $M a \beta e$ ') but further raised the bar as to which types of evidence were regarded sufficient. However, evidence of volume being more influential than other factors was difficult to come by for practical reasons (i.e. such studies did not exist) and scientific reasons (i.e. volume is a proxy for other factors thus can never be decisive).

Unsurprisingly, this move towards evidence-based medicine in justifying minimum volumes was celebrated by the hospital association:

Paragraph 3 of the agreement includes a procedural rule that stipulates that the setting of minimum volumes for certain services require an evidencebased process and scientific evaluation. [DKV, 4 Dec 03]

In 2004, having replaced the Hospital Committee, the GBA asked its newly created research institute, IQWiG, to examine the evidence of a volume-outcome relationship and to identify thresholds for total knee replacement (IQWiG 2005). Published in 2005, the IQWiG report noted that a volume-outcome relationship was plausible, but could not be proven in the absence of experimental studies (IQWiG 2005). In addition, the analysis of hospital data on volumes and outcomes for total knee replacement (using the outcome measures 'post-surgical mobility' and 'infection after surgery') resulted in conflicting findings, with one indicator showing a decline in desired outcomes at higher volumes and the other showing steady improvement. Individually and jointly the analyses of these indicators did not indicate that there is an ideal volume threshold. A later report by IQWiG relating to the treatment of very premature babies with very low birth weight also concluded that a causal relationship between volume and outcomes was likely, but could not be regarded as ultimately proven due to the absence of experimental studies (IQWiG 2008).

Since its inception the GBA has been committed to stringent evidence use, prompted by controversies over the reimbursement of pharmaceuticals and medical procedures, often involving legal action from manufacturers. There has also been a drive to professionalise procedures with several documents specifying its by-laws and code of practice. There was a notable effort to apply similarly robust approaches to decisions on minimum volumes, resulting in the commissioning of reviews and additional data analyses prepared by IQWiG. In commissioning these studies, the GBA explicitly followed established best practice, including the publication of protocols and peer review. In compliance with its by-laws, the GBA 
provided explicit rationales for its decisions, made this information publicly available and gave due consideration to reports commissioned from its research institute (GBA 2008).

Yet despite this emphasis on procedural robustness, the GBA found itself in a position in which it was impossible to base minimum volume decisions on evidence alone. This happened because the scientific evidence in support of specific threshold was inconclusive. In addition, being a membership organisation, the GBA continued to be exposed to the partisan interests of its member organisations, in one instance rejecting a study brought in by the hospital association which aimed to demonstrate that a volume-outcome relationship was inexistent (GBA 2010). There was thus substantial tension between two procedural rules, those set out in by-laws which aim at ensuring transparency and due process, and those associated with the corporatist nature of the GBA and the practice of negotiating consensus between the organised interests in health care. In the end, decisions about minimum volumes were taken by majority vote, which overruled the resistance of the hospital association. Yet this did not end the controversy.

\section{Adjudication by the Social Courts}

Following the introduction of minimum volumes for total knee replacement at a level of 50 per hospital and year and of increasing existing volumes for very premature babies from 14 to 30 (GBA 2013), several hospitals took legal action against sickness funds which had refused to pay for services delivered at lower numbers than required. Both cases led to a judicial review of the GBA decisions at state level (the Social Court of Berlin-Brandenburg, here referred to as 'state court'), and, subsequently, at federal level (by the Federal Social Court, here the 'federal court').

Three questions were considered in the courts specifically: (1). Whether the GBA was entitled to set minimum volumes that are binding on hospitals; $(2)$. whether the selection of services to apply minimum volumes to was in compliance with the law (i.e. SGB 5), especially whether these services were 'planable' (in the case of services for preterm babies) and whether there was sufficient evidence of a 'particular' relationship between volume and outcome; and (3). whether specific minimum volumes set had been sufficiently justified by the GBA, including by recourse to scientific evidence. 
On the first question, the state and federal courts upheld consistently that the GBA was entitled and mandated by parliament to set binding minimum volumes; however, the courts emphasised that, in compliance with German administrative law, the GBA had to explain and justify such decisions (BSG 2012a, b).

On the second question, the federal court ruled that services are legitimately selected if they are 'planable' in the sense that they can be accessed without posing additional risks to patients, arising, for example, from longer journeys to (fewer) hospitals. In relation to care for very premature babies, the court argued, referencing national and international studies, that the benefits for mothers-to-be outweighed the risks associated with longer travel (BSG 2012a: para 43). The court thus rejected an interpretation of 'planable' as 'elective' or 'predictable', as both terms would not consider the balance of risks and benefits to patients (BSG 2012a: para 30).

The courts also referred to research to clarify the meaning of the law with regard to the 'particular' causal relationship between volumes and outcomes required by law to justify specific minimum volumes. In 2011 , the state court ruled that a causal relationship could only be regarded as 'particular' if 'controlled studies' suggested a statistical relationship (LSG 2011: para 87). The state court thus aligned the wording of the law with the concept of the 'hierarchy of evidence' used in evidence-based medicine, which considers RCTs as the strongest research design to establish claims of causality.

This ruling was revised by the federal court in 2012 and confirmed in subsequent decisions in 2014 and 2015. The federal court argued that the law should not be interpreted as giving preference to particularly types of studies, especially since in the case of minimum volumes RCTs were neither practical nor ethical. Evidence from scientific studies would suffice if a causal relationship was 'probable and plausible' (BSG 2012b: para 31). However, such decisions would require additional support in the form of 'medical experience' (medizinische Erfahrungssätze) (BSG 2012b: 39). Such medical experience is often used in court decisions by inviting expert witnesses (Sachverständige), although in this case the courts largely relied on written statements from the GBA in justification if its position.

The third question discussed by the courts was whether specific minimum volumes had been sufficiently explained and justified by the GBA. The review of such justifications drew heavily on scientific evidence, although courts came to different conclusions about the level of justification needed for minimum volumes to be considered legal. For the state 
court in 2011, evidence was insufficient in the absence of experimental studies, which meant that the minimum volumes in question were unjustified (LSG 2011). Rejecting this ruling, the federal court argued - in line with its earlier reasoning - that minimum volumes were sufficiently justified if they were likely to improve outcomes, if the statistical association would be supported by 'medical experience' and if potential risks arising from minimum volumes (e.g. longer distances) would be outweighed by the potential benefits (BSG 2012a, 2014).

This weighing of risks and benefits led the federal court to come to different conclusions when considering specific minimum volumes. It argued that minimum volumes of 14 cases of very preterm babies per year were justified noting that 14 cases (roughly one per month) were sufficient to require the presence of a specialist team in a hospital. The existence of such a team would make quality improvements plausible. In a similar vein, it argued that 50 total knee replacements (roughly one per week on average) would be sufficient to require the hospital to employ a specialist team (BSG 2012a, 2014).

Using the same rationale, the federal court rejected minimum volumes of 30 per year for very preterm babies on the grounds that the higher threshold would increase the risks to those babies by excluding hospitals with lower volumes (but potentially providing good quality services) without necessarily increasing the benefits (BSG 2012b: para 60-61). It specifically cited four studies in support of this suggestion, one of which had been included in a systematic review (i.e. by IQWiG) and another one had been rejected by the GBA in an earlier version and was co-funded by the hospital association (GBA 2010; Kutschmann et al. 2012). While these studies made valid points about the limited ability of minimum volumes to separate high from low performing hospitals entirely accurately, the ruling gave prominence to a few selected studies while disregarding all the others included in previous scientific reviews.

In conclusion, the analysis of court decisions suggests that scientific evidence was of relevance to the legal adjudication on minimum volumes to establish whether specific minimum volumes set by the GBA were sufficiently justified in the eyes of the law. However, the decision itself was not based on evidence but on principles of plausibility and proportionality established in legal practice, which were then supported by research. Key to establishing conformity with the law was that the setting of minimum volumes was demonstrably proven to have been deliberated, with consideration given to the available evidence, and that a justification was provided that could be reviewed in court. 


\section{Discussion AND CONCLUSION}

This chapter has examined the development of minimum volume policy as a case study of health policy making in Germany. It specifically analysed the policy process and the way in which policy decisions were supported by evidence. It has argued that evidence use was mostly strategic: corporatist actors such as the hospital association and sickness funds commissioned research to support their aims; the hospital association consistently promoted evidence use (specifically the 'highest' level of evidence such as RCTs, which for minimum volumes does not exist) as a cornerstone of decisions on specific minimum volumes; it also brought in its own, i.e. cofunded, studies to underline its position that minimum volumes do not make a meaningful contribution to quality assurance.

The formation of the GBA and IQWiG in 2004 has changed the rules of the argumentative game, with new procedures developed for, and applied to, decision-making and scientific evidence use. Decision-making had previously been dominated by the consensual arrangements characteristic of corporatism. Consensual arrangements have been maintained in the GBA to some extent, however, decisions are eventually taken by majority vote, which means that resistance by providers can be overcome provided there is a majority. Decision-making procedures have become more rule-based, for example as they relate to commissioning evidence reviews from the IQWIG and considering its findings. This suggests that scientific evidence has become a substantial aspect of the GBA's approach to legitimising its decisions in relation to minimum volumes. This chimes with findings from Boswell (2008), as well as Bijker et al. (2009), which describe the transfer of scientific authority to decision-making bodies helping them to legitimise their actions. Similar observations have been made in relation to decisions involving HTA where the legislator has recently tightened the framework for decisions for inpatient services preventing the GBA to exclude services in the absence of evidence. New hospital services have to be proven to be either less effective than existing treatments or harmful, thus setting a high bar to evidentiary support for decisions about service exclusions (Olberg et al. 2014).

Still, in relation to minimum volumes the analysis also echoes findings that emphasise the negotiated nature of decisions (Etgeton 2009), suggesting that policy actors who are constituent members of the GBA engage in strategic uses of evidence to support their claims and promote their interests. Corporatist structures have changed and become more pluralist, 
adversarial and less consensus oriented. While some have argued that the GBA is particularly well placed for taking unpopular decisions in contested policy fields such as service exclusions from the public benefits package (Gerlinger 2010), the present state of affairs suggests that such decisions often end up in court. Courts then weigh the scientific evidence provided in support of a decision to establish whether the GBA has provided sufficient justification, although cognisant (perhaps increasingly so) of the limits of such evidence. This analysis suggests however that substantive disagreements between different organised interests do not disappear by evoking the authority of scientific evidence. Evidence use as 'technocratic fix' is unlikely to solve the legitimacy problems of organisations charged with unpopular decisions (Syrett 2003). Decisions that directly affect the interests of policy actors, perhaps especially so if these have financial implications and impact on notions of professional autonomy, are likely to remain contested and have a fair chance to require legal adjudication. The GBA is routinely taken to court by pharmaceutical producers (and sometimes patients) contesting decisions to exclude medicinal products from public reimbursement, which is a well-trodden (though not necessarily successful) avenue given that access to legal review is easy in the German legal system. In this case here, smaller hospitals are particularly likely to be affected by minimum volumes and while the hospital association opposed the policy almost throughout (although there are signs of partial acceptance following repeated confirmation by the judiciary (DKG 2014)) hospitals affected by the policy have found their interests directly at stake and have sought legal redress individually.

The policy process analysed here arguably does not tell the full story of minimum volumes, as it focuses on three specific stages of decision-making while largely ignoring the dynamics of agenda-setting prior to the parliamentary debate, and the actual impact of minimum volumes in practice. There is now clear evidence that minimum volume regulation is widely ignored by hospitals and sickness funds are incapable of retrieving funding from hospitals if services turn out to have been delivered in volumes below the threshold (de Cruppé et al. 2014; Peschke et al. 2014).

Court decisions also have tended to directly affect how the GBA went about making decisions, with some noting that the first court cases led to more attention given to future evidentiary support for decisions. It also led to the GBA ceasing to introduce further minimum volumes. Meanwhile, sickness funds have asked parliament to change the wording of the law to reduce the requirement on evidentiary support for minimum volumes 
(Leber 2014). In December 2015, a new law (the Act to Reform the Structures of Hospital Provision, KHSG) removed the phrase in besonderem Maße' (i.e. the particular relationship of volume and outcome) from the SGB 5 to make specific minimum volumes more defensible in court and introduce a process that would make it easier for sickness funds to withhold funding from hospitals for services under the threshold. Whether this will increase the number of minimum volumes introduced by the GBA in future and, indeed, further changes the balance between payers and providers in the still corporatist system of health policy making in Germany remains to be seen.

The analysis above has shown that various forms of strategic evidence use dominate the example of minimum volume policy in Germany. While it is clear that strategic use of evidence does not entirely preclude notions of 'evidence-based policy' - as evidence can also have a substantive impact on decisions - this analysis suggests that expectations of 'instrumental' evidence use are likely to be disappointed. Changes in corporatist decisionmaking, namely the formation of the GBA, have brought about new opportunities for evidence use, necessitated by the GBA's need to legitimise its decisions, including in court. But this has not reduced the potential for contestation or has fully established the idea of instrumental (i.e. objective) evidence use.

These findings hint at the contextual nature of evidence use in policymaking, which is shaped by the specific institutional arrangements of health care governance and the wider political system that influence the motivation of policy actors and organisations to use evidence to legitimise decisions. While the case of minimum volumes has shown that evidentiary support is necessary for such GBA decisions, evidence was not the only, or indeed most relevant, source of legitimacy, as legitimation is also derived from parliamentary law-making, corporatist governance and legal adjudication by the judiciary.

\section{REFERENCES}

Bandelow, N. 2004. Akteure und Interessen in der Gesundheitspolitik: Vom Korporatismus zum Pluralismus? Politische Bildung 37 (1): 49-63.

- 2009. Health governance in the aftermath of traditional corporatism: One small step for the legislator, one giant leap for the subsystem? German Policy Studies 5 (1): 43-63.

Bijker, W.E., R. Bal, and R. Hendriks. 2009. The paradox of scientific authority. The role of scientific advice in democracies. Cambridge, MA: MIT Press. 
Birkmeyer, J.D., S.R. Finlayson, A.N. Tosteson, S.M. Sharp, A.L. Warshaw, and E.S. Fisher. 1999. Effect of hospital volume on in-hospital mortality with pancreaticoduodenectomy. Surgery 125 (3): 250-256.

Birkmeyer, J.D., A.E. Siewers, E.V. Finlayson, T.A. Stukel, F.L. Lucas, I. Batista, H.G. Welch, and D.E. Wennberg. 2002. Hospital volume and surgical mortality in the United States. New England Journal of Medicine 346 (15): 1128-1137.

Birkmeyer, J.D., T.A. Stukel, A.E. Siewers, P.P. Goodney, D.E. Wennberg, and F.L. Lucas. 2003. Surgeon volume and operative mortality in the United States. New England Journal of Medicine 349 (22): 2117-2127.

Blum, S., and K. Schubert, eds. 2013. Policy analysis in Germany. Bristol: Policy Press.

BMGS. 2004. Beschluss des Gemeinsamen Bundesausschusses nach § 91 Abs. 7 des Fünften Buches Sozialgesetzbuch (SGB V) zur Aufnahme in den Mindestmengenkatalog nach § 137 Abs. I Satz 3 Nr. 3 SGB V vom 21. September 2004. Berlin, Bundesministerium für Gesundheit und Soziale Sicherung.

—. 2005. Bekanntmachung eines Beschlusses des Gemeinsamen Bundesausschusses nach $\$ 91$ Abs. 7 des Fünften Buches Sozialgesetzbuch (SGB V) zur Festlegung einer Mindestmenge nach § 137 Abs. I Satz 3 SGB V vom 16. August 2005. Berlin, Bundesministerium für Gesundheit und Soziale Sicherung.

Boswell, C. 2008. The political functions of expert knowledge: Knowledge and legitimation in European Union immigration policy. Journal of European Public Policy 15 (4): 471-488.

BSG. 2012a. Urteil vom 12 September, B 3 KR 10/12 R. Kassel, Bundessozialgericht.

—. 2012b. Urteil vom 18 Dezember, B l KR 34/12 R. Kassel, Bundessozialgericht.

—. 2014. Urteil vom 14 Oktober 2014, B l KR 33/13 R. Kassel, Bundessozialgericht.

Bundestag. 2001a. Bericht des Ausschusses für Gesundheit, 14. Wahlperiode, Drucksache 14/7862. Berlin, Deutscher Bundestag.

- 2001b. Beschlussempfehlung des Ausschusses für Gesundheit, 14. Wahlperiode, Drucksache 14/7824. Berlin, Deutscher Bundestag.

_. 2002a. Beschlussempfehlung des Vermittlungsausschusses zu dem Gesetz zur Einführung des diagnose-orientierten Fallpauschalensystems für Krankenhäuser (Fallpauschalengesetz - FPG), 14. Wahlperiode, Drucksache 14/8362. Berlin, Deutscher Bundestag.

- 2002b. Gesetz zur Einführung des diagnose-orientierten Fallpauschalensystems für Krankenhäuser (Fallpauschalengesetz - FPG). Bundesgesetzblatt 1: $1412-1438$.

Busse, R., and M. Blümel. 2014. Germany: Health system review. Health Systems in Transition 10 (2): 1-296. 
de Cruppé, W., M. Malik, and M. Geraedts. 2014. Umsetzung der Mindestmengenvorgaben: Analyse der Krankenhausqualitätsberichte. Deutsches Ärzteblatt 111 (33-34): 549-555.

DKG. 2014. Positionen der Deutschen Krankenhausgesellschaft zur Weiterentwicklung der Qualitätssicherung und der Patientensicherheit. Berlin: Deutsche Krankenhausgesellschaft.

Etgeton, S. 2009. Patientenbeteiligung in den Strukturen des Gemeinsamen Bundesausschusses. Gesundheitsschutz 52 (1): 104-110.

Finlayson, E.V., P.P. Goodney, and J.D. Birkmeyer. 2003. Hospital volume and operative mortality in cancer surgery: A national study. Archives of Surgery 138 (7): 721-725.

Francke, R., and D. Hart. 2008. Einführung in die rechtlichen Aspekte bei HTAs. Zeitschrift fuer Evidenz, Fortbildung und Qualität im Gesundheitswesen 102: 63-68.

GBA. 2008. Verfahrensordnung des Gemeinsamen Bundesausschusses (in its version of January 2014). Berlin: Gemeinsamer Bundesausschuss.

. 2009. Bekanntmachung eines Beschlusses des Gemeinsamen Bundesausschusses zur Versorgung von Früh- und Neugeborenen vom 20. Bundesanzeiger 195: 4450 .

- 2010. Tragende Gründe zum Beschluss des Gemeinsamen Bundesausschusses über eine Änderung der Anlage 1 der Mindestmengevereinbarung: Mindestmengen bei Früh- und Neugeborenen vom 17. Juni. Berlin: Gemeinsamer Bundesausschuss.

- 2013. Geschaeftsbericht 2012. Berlin: Gemeinsamer Bundesausschuss.

Geraedts, M. 2002. Evidenz zur Ableitung von Mindestmengen in der Medizin. Gutachten im Auftrag der Bundesärztekammer. Düsseldorf, HeinrichHeine-Universität.

Gerlinger, T. 2010. Health care reform in Germany. German Policy Studies 6 (1): $107-142$.

Greenhalgh, T., and J. Russell. 2007. Reframing evidence synthesis as rhetorical action in the policy making drama. Politiques de Santé 1: 34-42.

Gress, S., D. Niebuhr, H. Rothgang, and J. Wasem. 2005. Criteria and procedures for determining benefits packages in health care. A comparative perspective. Health Policy 73: 78-91.

Hansson, F. 2006. Organizational use of evaluations: Governance and control in research evaluation. Evaluation 12 (2): 159-178.

Hind, D. 2007. The threat to reason: How the enlightenment was hijacked and how we can reclaim it. London: Verso.

IQWiG. 2005. Entwicklung und Anwendung von Modellen zur Berechnung von Schwellenwerten bei Mindestmengen für Knie-Totalendoprothese. Abschlussbericht. Cologne: Institut für Qualität und Wirtschaftlichkeit im Gesundheitswesen. 
2006. Entwicklung und Erstellung eines Prognosemodells zur Ermittlung der Auswirkungen von Schwellenwerten auf die Versorgung. Abschlussbericht. Cologne: Institut für Qualität und Wirtschaftlichkeit im Gesundheitswesen.

. 2008. Zusammenhang zwischen Leistungsmenge und Ergebnis bei der Versorung von Früh- und Neugeborenen mit sehr geringem Geburtsgewicht. Abschlussbericht. Cologne, Institut für Qualität und Wirtschaftlichkeit im Gesundheitswesen.

- 2015. Aufgaben und Ziele des IQWiG. https://www.iqwig.de/de/ ueber-uns/aufgaben-und-ziele.2946.html. Accessed 14 Jan 2015.

Jun, U., and K. Grabow. 2008. Mehr Expertise in der deutschen Politik? Zur Übertragbarkeit des "Evidence-based policy approach". Bertelsmann Stiftung: Gütersloh.

Kieslich, K. 2012. Social values and health priority setting in Germany. Journal of Health Organization and Management 26 (3): 374-383.

Klingler, C., S.M. Shah, A.J. Barron, and J.S. Wright. 2013. Regulatory space and the contextual mediation of common functional pressures: Analyzing the factors that led to the German Efficiency Frontier approach. Health Policy 109: 270-280.

Kloten, N. 2006. Wissenschaftliche Beratung der Politik: Befund und Auftrag. Politikberatung in Deutschland. Heidelberger Akademie der Wissenschaften. Wiesbaden, VS Verlag für Sozialwissenschaften: 123-145.

Knieps, F. 2009. Evidence based health policy oder wissenschaftlich verbrämter Lobbyismus - Die Verwertung wissenschaftlicher Erkenntnisse in der Gesundheitspolitik. Zeitschrift für Evidenz, Fortbildung und Qualität im Gesundheitswesen 103 (5): 273-280.

Kutschmann, M., S. Bungard, J. Kötting, A. Trümner, C. Fusch, and C. Veit. 2012. Versorgung von Frühgeborenen mit einem Geburtsgewicht unter 1250 g. Deutsches Ärzteblatt 109 (31-32): 519-528.

Landwehr, C., and K. Böhm. 2011. Delegation and institutional design in healthcare rationing. Governance: An International Journal of Policy, Administration, and Institutions 24 (4): 665-688.

Leber, W.-D. 2014. Mindestmengen. AQUA-Tagung „Qualität kennt keine Grenzen“, Göttingen, May 14. http://tagung-2014.sqg.de/2014/ppt/P4-1fol_G\%C3\%B6ttingen_2014_05_14_AQUA_Mindestmengen_Dr\%20Leber_ final.pdf. Accessed 17 Jan 2015.

Lehmbruch, G. 1988. Der Neokorporatismus der Bundesrepublik im internationalen Vergleich und die „Konzertierte Aktion im Gesundheitswesen “. Neokorporatismus und Gesundheitswesen. G. Gäfgen. Baden-Baden, Nomos: 11-32.

Lijphart, A., and M. Crepaz. 1991. Corporatism and consensus democracy in eighteen countries: Conceptual and empirical linkages. British Journal of Political Science 21 (2): 235-246.

Littlejohns, P. 2012. Social values and health priority setting in England: 'values' based decision making. Journal of Health Organization and Management 26 (3): 363-371. 
LSG. 2011. Urteil vom 17. August 2011, L 7 KA 77/08 KL. Potsdam, Landessozialgericht Berlin-Brandenburg.

Luft, H.S., J.P. Bunker, and A.C. Enthoven. 1979. Should operations be regionalized? The empirical relation between surgical volume and mortality. The New England Journal of Medicine 301 (25): 1364-1369.

Majone, G. 1989. Evidence, argument, and persuasion in the policy process. Yale: Yale University Press.

Marmot, M.G. 2004. Evidence based policy or policy based evidence? Willingness to take action influences the view of the evidence - Look at alcohol. BMJ 328: 906-907.

Mayntz, R. 2009. Speaking truth to power: Leitlinien für die Regelung wissenschaftlicher Politikberatung. Zeitschrift fuer Public Policy, Recht und Management 1: 5-16.

McNulty, J. 2012. Symbolic uses of evaluation in the international aid sector: Arguments for critical reflection. Evidence \& Policy: A Journal of Research, Debate and Practice 8 (4): 495-509.

MMV. 2002. Vereinbarung gemäss Paragraph 137 Abs. 1 Satz 3 Nr. 3 SGB 5 - Mindestmengenvereinbarung.

Olberg, B., M. Perleth, and R. Busse. 2014. The new regulation to investigate potentially beneficial diagnostic and therapeutic methods in Germany: Up to international standard? Health Policy 117: 135-145.

Perleth, M., B. Gibis, and B. Goehlen. 2009. A short history of health technology assessment in Germany. International Journal of Technology Assessment in Health Care 25 (Suppl 1): 112-119.

Peschke, D., U. Nimptsch, and T. Mansky. 2014. Umsetzung der Mindestmengenvorgaben: Analyse der DRG-Daten. Deutsches Ärzteblatt 111 (33-34): $556-563$.

Rathmann, W., and J. Windeler. 2002. Zusammenhang zwischen Behandlungsmenge und Behandlungsqualität. Evidenzbericht. Essen: Medizinischer Dienst der Spitzenverbände der Krankenkassen.

Renn, O. 1995. Style of using scientific expertise: A comparative framework. Science and Public Policy 22 (3): 147-156.

Siefken, S.T. 2007. Expertenkommissionen im politischen Prozess. Eine Bilanz zur rot-grünen Bundesregierung 1998-2005. Wiesbaden: VS Verlag für Sozialwissenschaften.

Strueck, C. 2013. Public interest groups and policy analysis: A push for evidencebased policy-making? In Policy analysis in Germany, ed. S. Blum and K. Schubert, 217-230. Bristol: Policy Press.

Suchman, M.C. 1995. Managing legitimacy: Strategic and institutional approaches. Academy of Management Review 20 (3): 571-610. 
Syrett, K. 2003. A technocratic fix to the 'legitimacy problem'? The Blair Government and health care rationing in the United Kingdom. Journal of Health Politics, Policy and Law 28 (4): 715-746.

- 2004. Impotence or importance? Judicial review in an era of explicit NHS rationing. Modern Law Review 67 (2): 289-321.

Tsebelis, G. 2011. Veto players: How political institutions work. Princeton: Princeton University Press.

Weingart, P. 1999. Scientific expertise and political accountability: Paradoxes of sciences in politics. Science and Public Policy 26 (3): 151-161.

Weiss, C.H. 1979. The many meanings of research utilization. Public Administration Review 39 (5): 426-431.

Open Access This chapter is licensed under the terms of the Creative Commons Attribution 4.0 International License (http://creativecommons.org/licenses/ by $/ 4.0 /$ ), which permits use, sharing, adaptation, distribution and reproduction in any medium or format, as long as you give appropriate credit to the original author(s) and the source, provide a link to the Creative Commons license and indicate if changes were made.

The images or other third party material in this chapter are included in the chapter's Creative Commons license, unless indicated otherwise in a credit line to the material. If material is not included in the chapter's Creative Commons license and your intended use is not permitted by statutory regulation or exceeds the permitted use, you will need to obtain permission directly from the copyright holder.

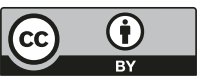

